\title{
PENGARUH WAKTU MASERASI TERHADAP AKTIVITAS ANTIOKSIDAN EKSTRAK DAUN PEGAGAN (Centella asiatica (L.) Urban)
}

\section{Effect of maceration time on antioxidant activity of pegagan (Centella asiatica (L.) Urban) leaf extract.}

\author{
${ }^{1}$ Ni Komang Triana Rahayu, ${ }^{2}$ I Dewa Gede Mayun Permana*, ${ }^{2}$ G. A. Kadek Diah Puspawati \\ ${ }^{1}$ Mahasiswa Program Studi Ilmu dan Teknologi Pangan, Fakultas Teknologi Pertanian, Unud \\ ${ }^{2}$ Dosen Program Studi Ilmu dan Teknologi Pangan, Fakultas Teknologi Pertanian, Unud \\ Kampus Bukit Jimbaran, Badung-Bali
}

\begin{abstract}
This research aimed to determine the effect of maceration time on the antioxidant activity of pegagan leaf extract and to determine the best maceration time with highest antioxidant activity of pegagan leaf extract. The experimental design used was Completely Randomized Design with maceration time duration there were 18, 24, $30,36,42$, and 48 hours. All of the treatment repeated three times to obtained 18 units of experiments. The data analyzed by analyze of variance, if the treatment had a significant effect followed by The Duncan Test. The results showed that the maceration time treatment had a significant effect on yield, total phenolik, total flavonoid, total tannin and antioxidant activity of pegagan leaf extract. The 24 hour maceration time was the best treatment with antioxidant activity $66.67 \%, \mathrm{IC}_{50} 632.82 \mathrm{ppm}$, a yield of $24.30 \%$, a total phenolik of 57.85 $\mathrm{mgGAE} / \mathrm{g}$, a total flavonoid of $105.28 \mathrm{mgQE} / \mathrm{g}$. total tannin $54.09 \mathrm{mgTAE} / \mathrm{g}$.
\end{abstract}

Keywords: antioxidant activity, pegagan leaf, maceration time

\section{PENDAHULUAN}

Tanaman pegagan (Centella asiatica (L) Urban) merupakan tanaman yang sering dianggap sebagai gulma, daun berbentuk menyerupai ginjal dengan pangkal melekuk kedalam. Sebagian masyarakat telah memanfaatkan pegagan sebagai lalapan segar, minuman dan obat tradisional. (Rachmatiah et al., 2015; Rohmawati, 2015). Pegagan telah dilaporkan sebagai antiinflamasi, penambah nafsu makan, pereda lepra, kompres luka, meningkatkan sistem imun tubuh, meningkatkan vitalitas dan daya ingat (Sutardi, 2016; Dahono, 2013). Pegagan mengandung senyawa seperti alkaloid, saponin, tanin, flavonoid, triterpenoid saponin, dan glikosida (Bermawie, 2008; wientarsih et al. 2013). Senyawa yang paling banyak terdapat pada pegagan yaitu asiatikosida (Sutardi, 2016).

*Korespondensi Penulis

Email : ign.mayun@unud.ac.id

Senyawa tanin dan flavonoid pada pegagan berfungsi sebagai antioksidan yang dipercaya mampu menetralisir radikal bebas dalam tubuh.

Cara yang dapat dilakukan untuk memperoleh antioksidan alami pada daun pegagan dengan cara ekstraksi. Ekstraksi merupakan proses perpindahan zat aktif pada bahan yang ditarik menggunakan pelarut tertentu. Faktor-faktor yang mempengaruhi ekstraksi yaitu metode ekstraksi, suhu, konsentrasi pelarut, jenis pelarut, dan waktu ekstraksi (Utami., 2009). Metode maserasi adalah metode yang paling banyak digunakan untuk mengektraksi bahan alam. Metode maserasi merupakan ekstraksi dengan pelarut cara dingin tidak memerlukan proses pemanasan sehingga tidak merusak zat aktif dalam pegagan (Salamah dan Nurushoimah., 2014). Pramono dan Ajiastuti (2004) telah melaporkan maserasi menggunakan pelarut 
etanol $70 \%$ dapat menyari senyawa bioaktif pada pegagan lebih banyak. Penelitian tentang waktu maserasi yang tepat pada daun pegagan untuk menghasilkan aktivitas antioksidan tertinggi belum dikaji. Waktu ekstraksi yang terlalu singkat mengakibatkan tidak semua senyawa aktif pada daun pegagan terekstrak dan waktu yang terlalu lama mengakibatkan senyawa aktif pada daun pegagan yang terekstrak menjadi rusak (Utami, 2009).

Tujuan penelitian ini yaitu menentukan pengaruh waktu maserasi terhadap aktivitas antioksidan ekstrak daun pegagan dan menentukan waktu maserasi terbaik untuk menghasilkan ekstrak daun pegagan dengan aktivitas antioksidan tertinggi.

\section{METODE PENELITIAN}

\section{Tempat dan Waktu}

Penelitian ini dilaksanakan di Laboratorium Analisis Pangan, Laboratorium Pengolahan Pangan dan Laboratorium Rekayasa dan Pengendalian Mutu Program Studi Ilmu dan Teknologi Pangan, Fakultas Teknologi Pertanian, Universitas Udayana, Agrokomplek, Kampus Sudirman. Penelitian ini dilaksanankan pada bulan AgustusNopember 2019.

\section{Bahan dan Alat}

Bahan yang digunakan adalah daun pegagan segar berwarna hijau agak tua dengan diameter $\pm 5 \mathrm{~cm}$ dan diambil pada pukul 08.00 10.00 yang diperoleh di Desa Penebel Tabanan, Bali. Bahan kimia yang digunakan terdiri dari Aquades (merck), etanol PA (Merck), Reagen Folin-Ciocalteu (Merck), $\begin{array}{lllll}\mathrm{NaNO}_{2} & \text { (Merck), } & \mathrm{AlCl}_{3} & \text { (Merck), } & \mathrm{Na}_{2} \mathrm{CO}_{3}\end{array}$
(Merck), methanol (Merck), asam galat (Merck), reagen follin denis (Merck), kuersetin (Sigma Aldrich) dan DPPH (Himedia).

Alat yang digunakan yaitu blender (Pilliph), ayakan 60 mesh (Retsch), timbangan analitik (shimadzu), aluminium foil, pipet volume (pyrex), gelas ukur (pyrex), mikro pipet (pyrex), spektrofotometer UV-Vis (Genesys IOS Uv-Vis), corong kaca, rotary vakum evaporator (Ika Labortechnic), vortex (MixMax II), kertas saring whatman no. 1 dan alatalat gelas lainnya.

\section{Rancangan Percobaan}

Penelitian ini mengunakan rancangan acak lengkap (RAL) dengan perlakuan waktu maserasi (W) terdiri dari 6 taraf meliputi 18 jam, 24 jam, 30 jam, 36 jam, 42 jam, dan 48 jam. Perlakuan ini diulang sebanyak 3 kali sehingga diperoleh 18 unit percobaan. Data yang diperoleh dianalisis dengan sidik ragam dan apabila perlakuan berpengaruh terhadap parameter yang diamati, maka akan dilanjutkan uji Duncan (Steel dan Torrie.,1993).

\section{Pelaksanaan Penelitian}

\section{Pembuatan Bubuk Daun Pegagan}

Persiapan sampel dimulai dengan daun pegagan disortasi, dicuci bersih dan ditiriskan, kemudian dikering anginkan selama 7 hari. Selanjutnya dihaluskan dengan blender kemudian diayak dengan ayakan 60 mesh.

\section{Ekstraksi Bubuk Daun Pegagan}

Daun pegagan diekstrak menggunakan metode maserasi. Sebanyak 15 gram bubuk daun pegagan dilarutkan dengan $150 \mathrm{~mL}$ pelarut etanol $70 \%$, Perbandingan bahan dengan pelarut adalah $1: 10(\mathrm{~b} / \mathrm{v})$, kemudian 
dimaserasi dalam waktu 18 jam, 24 jam, 30 jam dan 36 jam, 42 jam dan 48 jam pada suhu kamar. Setelah itu, larutan disaring dengan kertas saring whatman no 1. Filtrat kemudian dipekatkan menggunakan rotary vakum evaporator dengan suhu $40^{\circ} \mathrm{C}$ dan tekanan 100mBar. Ekstrak daun pegagan yang diperoleh selanjutnya dianalisis rendemen, total flavonoid, total tanin, total fenolik dan aktivitas antioksidan.

\section{HASIL DAN PEMBAHASAN}

\section{Rendemen}

Hasil sidik ragam menunjukkan bahwa waktu maserasi berpengaruh nyata $(\mathrm{P}<0,05)$ terhadap rendemen ekstrak daun pegagan. Rendemen ekstrak daun pegagan dalam penelitian ini sebesar 23,17\% - 26,13\%. Grafik rata-rata rendemen (\%) ekstrak daun pegagan dilihat pada Gambar 1.

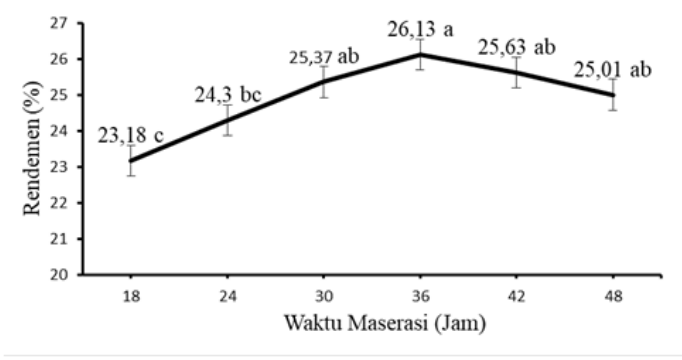

Gambar 1. Rata-rata rendemen (\%) ekstrak daun pegagan

Gambar 1 menunjukan rendemen tertinggi diperoleh dari perlakuan waktu maserasi 36 jam sebesar 26,13\%. Rendemen ekstrak terendah diperoleh dari perlakuan waktu maserasi 18 jam sebesar 23,17\%. Rendemen yang dihasilkan mengalami peningkatan dari waktu 18 jam hingga waktu 36 jam. Hal ini dikarenakan sampel dapat bersentuhan dengan pelarut lebih lama sehingga kuantitas bahan yang terekstrak semakin banyak sampai batas waktu optimum. Namun setelah melewati waktu optimum rendemen yang dihasilkan berbeda tidak nyata dan cenderung tetap (Yuliantari et al., 2017). Rendemen cenderung tetap setelah melewati waktu optimum disebabkan oleh komponen yang terdapat pada bahan memiliki jumlah yang terbatas dan pelarut yang digunakan memiliki batas kemampuan untuk melarutkan bahan, sehingga walaupun waktu ekstraksi diperpanjang zat terlarut dalam bahan sudah tidak terekstrak lagi (Yulianti et al., 2014). Hal tersebut juga sejalan dengan yang dilaporkan Kemit (2016) dan Utami (2009) yang menyatakan bahwa waktu ekstraksi yang terlalu lama dan melewati batas optimum menyebabkan senyawa bioaktif menjadi rusak. Hasil rendemen pada penelitian ini lebih tinggi dibandingkan rendemen daun rambai laut yang dilaporkan oleh Wijaya et al. (2018) yakni sebesar $21,28 \%$ yang dimaserasi mengunakan etanol $70 \%$ selama 24 jam.

\section{Total Fenolik}

Hasil sidik ragam menunjukkan bahwa waktu maserasi berpengaruh sangat nyata $(\mathrm{P}<0,05)$ terhadap kadar total fenolik ekstrak daun pegagan. Grafik rata-rata total fenolik (mgGAE/g) ekstrak daun pegagan dilihat pada Gambar 2. 


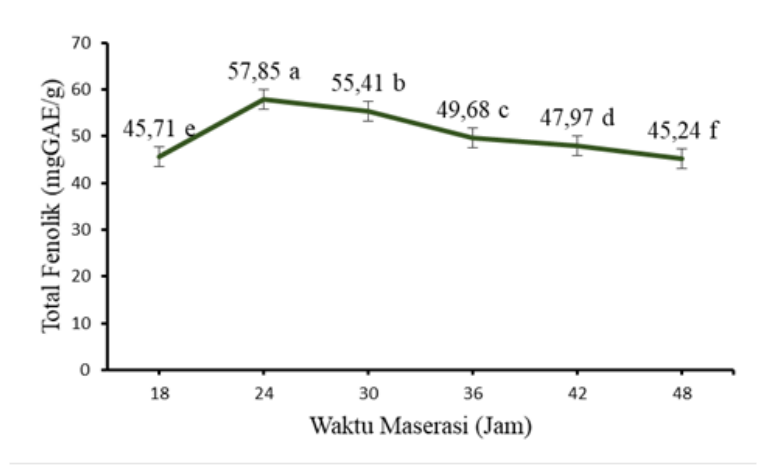

Gambar 2. Rata-rata total fenolik (mgGAE/g) ekstrak daun pegagan.

Gambar 2 menunjukan total fenolik ekstrak daun pegagan terendah terdapat pada perlakuan waktu maserasi 48 jam sebesar 45,24 mgGAE/g ekstrak. Total fenolik tertinggi terdapat pada perlakuan waktu maserasi 24 jam sebesar 57,85 mgGAE/g ekstrak. Waktu maserasi berpengaruh terhadap kadar total fenolik ekstrak daun pegagan. Total fenolik ekstrak daun pegagan mengalami peningkatan hingga batas optimum yaitu pada waktu maserasi 18 jam sampai 24 jam. Setelah melewati waktu maserasi 24 jam senyawa fenolik mengalami penurunan, hal ini dikarenakan waktu ekstraksi yang melebihi waktu optimum akan menyebabkan senyawa fenolik teroksidasi akibat kontak yang relatife lama dengan faktor lingkungan seperti oksigen (Chew et al., 2011). Kadar total fenolik daun pegagan dalam penelitian ini asal Tabanan berbeda dibandingkan dengan kadar total fenolik daun pegagan asal Solo yaitu sebesar 50,17 mgGAE/g ekstrak (Artanti et al.,2014). Kondisi ini diduga karena pengaruh dari kondisi lingkungan yang berbeda, sehingga metabolit sekunder yang dihasilkan juga berbeda.

\section{Total Flavonoid}

Hasil sidik ragam menunjukan bahwa waktu maserasi berpengaruh nyata $(\mathrm{P}<0,05)$ terhadap kadar total flavonoid ekstrak daun pegagan. Grafik rata-rata total flavonoid (mgQE/g) ekstrak daun pegagan dilihat pada Gambar 3.

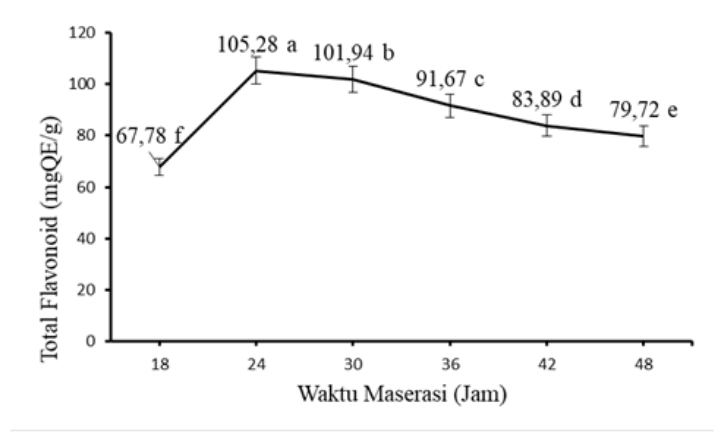

Gambar 3. Rata-rata total flavonoid (mgQE/g) ekstrak daun pegagan.

Gambar 3 menunjukan total flavonoid terendah terdapat pada perlakuan dengan Waktu maserasi 18 jam sebesar 67,78 mgQE/g ekstrak. Total flavonoid tertinggi terdapat pada perlakuan dengan waktu maserasi 24 jam sebesar 105,28 mgQE/g ekstrak. Senyawa flavonoid mengalami peningkatan dari waktu maserasi 18 jam sampai 24 jam dan setelah melewati waktu 24 jam total flavonoid mengalami penurunan. Hal ini menunjukan bahwa waktu optimum untuk mendapatkan total flavonoid tertinggi pada waktu maserasi 24 jam sejalan dengan pernyataan Utami (2009) yang melaporkan bahwa waktu ekstraksi terlalu singkat menyebabkan tidak semua senyawa flavonoid dapat terekstrak dan waktu ekstraksi terlalu lama menyebabkan senyawa flavonoid rusak. Total flavonoid daun pegagan dalam penelitian ini asal Tabanan berbeda dibandingkan dengan total flavonoid daun pegagan asal Solo yaitu sebesar $85,95 \mathrm{mgQE} / \mathrm{g}$ 
ekstrak (Artanti et al.,2014). Kondisi ini diduga karena pengaruh dari kondisi lingkungan yang berbeda, sehingga metabolit sekunder yang dihasilkan juga berbeda.

\section{Total Tanin}

Hasil sidik ragam menunjukan bahwa waktu maserasi berpengaruh nyata $(\mathrm{P}<0,05)$ terhadap kadar total tanin ekstrak daun pegagan. Grafik rata-rata total tanin (mgTAE/g) ekstrak daun pegagan dilihat pada Gambar 4.

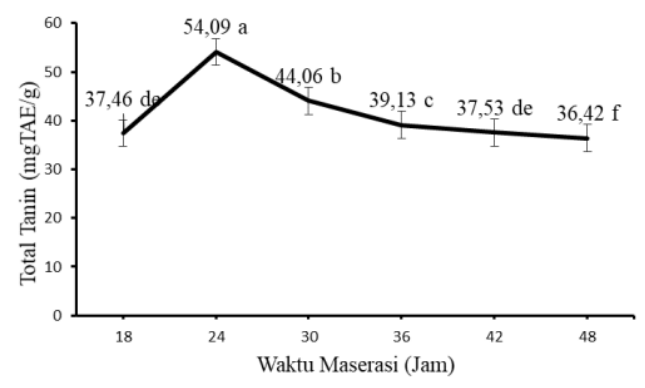
Gambar 4. Rata-rata total tanin (mgTAE/g)
ekstrak daun pegagan

Gambar 4 menunjukan total tanin yang tertinggi diperoleh dari perlakuan waktu maserasi 24 jam sebesar 54,09 $\mathrm{mgTAE} / \mathrm{g}$ ekstrak dan perlakuan waktu maserasi terendah diperoleh dari waktu maserasi 48 jam sebesar 36,42 mgTAE/g ekstrak Perlakuan waktu maserasi 18 jam sebesar 37,46mgTAE/g yang tidak berbeda nyata dengan perlakuan maserasi 42 jam sebesar 37,53 mgTAE/g ekstrak.

Total tanin mengalami peningkatan pada perlakuan waktu maserasi 18 jam sampai 24 jam. Meningkatnya total tanin sampai 24 jam dikarenakan lamanya waktu kontak antara senyawa tanin dan pelarut terus berlanjut sampai mencapai waktu optimum. kandungan total tanin menurun setelah melewati kondisi optimum pada waktu 24 jam disebabkan waktu kontak antara tanin dan pelarutnya terlalu lama mengakibatkan laju oksidasi meningkat. Lestari dan Wijana., (2010) menyatakan bahwa semakin lama waktu ekstraksi, kontak antara pelarut dan bahan akan semakin lama, sedangkan setiap bahan mempunyai batas optimum. Apabila waktu ekstraksi melampaui batas optimum menyebabkan waktu ekstraksi menjadi tidak berpengaruh karena senyawa mengalami oksidasi.

\section{Aktivitas Antioksidan}

Hasil sidik ragam menunjukan bahwa waktu maserasi berpengaruh nyata $(\mathrm{P}<0,05)$ terhadap aktivitas antioksidan ekstrak daun pegagan. Grafik rata-rata aktivitas antioksidan (\%) ekstrak daun pegagan dilihat pada Gambar 5 .

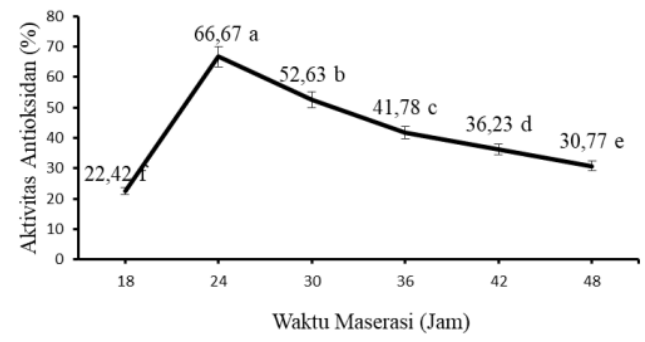

Gambar 5. Rata-rata aktivitas antioksidan (\%) ekstrak daun pegagan

Gambar 5 menunjukan aktivitas antioksidan yang terendah diperoleh waktu maserasi 18 jam sebesar 22,42\% dan perlakuan waktu maserasi tertinggi diperoleh waktu maserasi 24 jam sebesar 66,67\%. Aktivitas antioksidan meningkat hingga mencapai waktu optimum. Hal ini disebabkan karena total fenolik dan total flavonoid pada waktu 18 jam sampai 24 
jam mengalami peningkatan sehingga terdapat korelasi positif antara aktivitas antioksidan dengan total fenolik, total flavonoid dan total tanin, dimana semakin meningkat total fenolik, total flavonoid dan total tanin maka aktivitas antioksidan juga semakin meningkat (Prabandari, 2015). Namun, setelah mencapai waktu optimum aktivitas antioksidan ekstrak daun pegagan mengalami penurunan. Hal ini terjadi karena setelah batas waktu maserasi 24 jam total fenolik, total flavonoid dan total tanin mengalami penurunan.

\section{$\mathrm{IC}_{50}$}

Berdasarkan hasil analisis aktivitas antioksidan, waktu maserasi 24 jam memiliki persentase antioksidan tertinggi sehingga perlakuan ini dipilih untuk uji penentuan $\mathrm{IC}_{50}$. Grafik hubungan antara konsentrasi ekstrak dengan aktivitas antioksidan ekstrak daun pegagan dapat dilihat pada Gambar 6 .

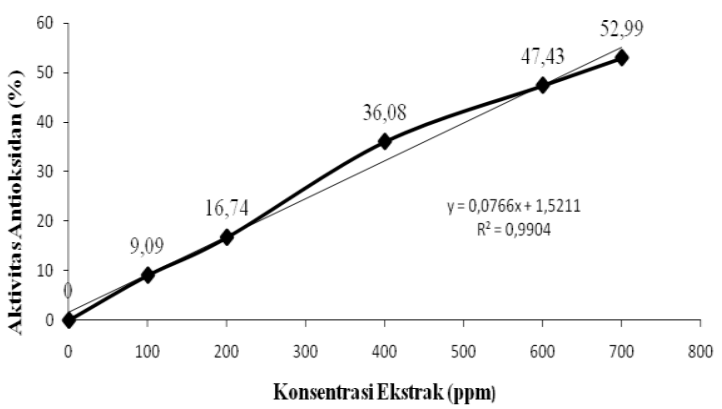

Gambar 6. Grafik hubungan konsentrasi ekstrak dengan aktivitas antioksidan ekstrak pegagan.

Berdasarkan analisis regresi linier diperoleh persamaan yaitu $\mathrm{y}=0,0766 \mathrm{x}+$ 1,5211 sehingga didapatkan $\mathrm{IC}_{50}$ sebesar $632,88 \mathrm{ppm}$. IC $\mathrm{IC}_{50}$ menggambarkan besarnya konsentrasi suatu senyawa yang mampu menghambat radikal bebas sebesar $50 \%$. Menurut Molyneux (2004) apabila suatu senyawa memiliki $\mathrm{IC}_{50}>500$ ppm menyatakan bahwa aktivitas antioksidan senyawa tersebut sangat lemah. Oleh karena itu, nilai $\mathrm{IC}_{50}$ dari ekstrak daun pegagan tergolong sangat lemah. Nilai IC $_{50}$ yang didapat lebih besar dari nilai $\mathrm{IC}_{50}$ yang dilaporkan oleh Rachmatiah et al. (2015) yaitu sebesar 65,66 ppm dan lebih kecil dibandingkan dengan nilai $\mathrm{IC}_{50}$ yang dilaporkan oleh Budiarti et al. (2014) yaitu sebesar $3.132 \mathrm{ppm}$.

Berdasarkan parameter yang di amati, meliputi rendemen yang terbaik pada $24 \mathrm{Jam}$, total fenolik terbaik pada waktu maserasi 24 jam, total flavonoid terbaik pada waktu maserasi 24 jam, total tanin terbaik pada waktu maserasi 24 jam aktivitas antioksidan terbaik didapatkan pada waktu 24 jam sehingga dapat disimpulkan waktu maserasi terbaik didapatkan pada waktu 24 jam dengan menghasilkan aktivitas antioksidan sebesar 66,67 \% dengan $\mathrm{IC}_{50}$ sebesar $632,88 \mathrm{ppm}$, rendemen sebesar $24,30 \%$, total fenolik sebesar $57,85 \mathrm{mgGAE} / \mathrm{g}$ ekstrak, total flavonoid sebesar 105,28 mgQE/g ekstrak total tanin sebesar 54,09 mgTAE/g ekstrak.

\section{KESIMPULAN DAN SARAN}

\section{Kesimpulan}

Berdasarkan hasil dan pembahasan penelitian maka dapat disimpulkan sebagai berikut.

1. Waktu maserasi berpengaruh nyata terhadap rendemen, kadar total fenolik, kadar total flavonoid, kadar total tanin dan aktivitas antioksidan ekstrak daun pegagan. 
2. Waktu maserasi daun pegagan terbaik pada waktu 24 jam menghasilkan aktivitas antioksidan sebesar $66,67 \%$ dengan $\mathrm{IC}_{50}$ sebesar 632,88 ppm, rendemen sebesar $24,30 \%$, total fenolik sebesar 57,85 mgGAE/g ekstrak, total flavonoid sebesar 105,28 mgQE/g ekstrak total tanin sebesar 54,09 mgTAE/g ekstrak.

\section{Saran}

Disarankan menggunakan waktu maserasi 24 jam dengan etanol $70 \%$ untuk mengekstrak daun pegagan.

\section{DAFTAR PUSTAKA}

Artanti, N. R.T. Dewi dan F. Maryani. 2014. Pengaruh Lokasi dan Pelarut Pengekstraksi Terhadap Kandungan Fitokimia dan Aktivitas Antioksidan Ekstrak Pegagan (Centella asiatica L. Urb). LIPI. 16(2) : 88-92

Asendy, D.A, I.W.R. Widarta dan K.A. Nocianitri. 2018. Pengaruh Waktu Maserasi Terhadap Aktivitas Antioksidan Ekstrak Kulit Buah Jeruk Lemon (Citrus Limon Linn). Jurnal Ilmu dan Teknologi Pangan. 7(3): 102-109.

Bermawie, N.S. Purwiyanti dan Mardika. 2008. Keragaman Sifat Morfologi, Hasil dan Mutu Flasma Nuftah Pegagan (Centella asiatika (L.) Urban). Balai Penelitian Tanaman Obat dan Aromatik. Bul.Litro. XIX (1) : 1-17

Blois, M.S. 1985. Antioxidant determinations by the use of a stable freeradical. Nature, 181:1199-1200.

Dahono. 2013. Manfaat Pegagagan. Loka Pengkajian Teknologi Pertanian (LPTP) Kepulauan Riau.

Erviana, L. A. Malik dan A. Najib. 2016. Uji Aktivitas Antiradikal Bebas Ekstrak Etanol Daun Kemangi (Ocimum Basilicum L.) Dengan Menggunakan Metode Dpph. Fakultas Farmasi,
Universitas Muslim Indonesia. Jurnal Fitofarmaka Indonesia. 3(2) : 164-168.

Kemit, N., I.W.R. Widarta, dan K.A. Nocianitri. 2016. Pengaruh jenis pelarut dan waktu maserasi terhadap kandungan senyawa flavonoid dan aktivitas antioksidan ekstrak daun alpukat (Persea Americana Mill). Jurnal Ilmu dan Teknologi Pangan. 5(2):130-141

Khaira, K. 2010. Menangkal Radikal Bebas Dengan Antioksidan. Jurnal Saintek. II(2) : 183-187

Kuncahyo, I. 2007. Uji Aktivitas Antioksidan Ekstrak Belimbing Wuluh (Averrhoc belimbing, L). Seminar Nasional Teknologi 2007 (SNT 2007). Yogyakarta.

Parwata, I.M.O.A. 2016. Antioksidan (Bahan Ajar). Denpasar. Universitas Udayana

Pramono, S dan D. Ajiastuti. 2004. Standardisasi ekstrak herba pegagan (Centella asiatica.(L.)Urban) berdasarkan kadar asiatikosida secara KLT-densitometri. Majalah Farmasi Indonesia. Fakultas Farmasi Universitas Gadjah Mada. Yogyakarta. 15(3) : 118 - 123.

Rachmatiah,T.F.E. Putri dan R.T. Dewi. 2015. Aktivitas Ekstrak Etanol Daun Pegagan Merah (Centella asiatica (L.) Urban. Var. Manoko) Sebagai Aktivitas Antioksidan dan Antidiabetes Secara In Vitro. Serpong. Lembaga Ilmu Pengetahuan Indonesia. Saintech Farma 8(2) : 1417

Salamah, N dan Nurushoimah. 2014. Uji Aktivitas Antioksidan Ekstrak etanol Herba Pegagan (Centella asiatica (L.) Urban) Dengan Metode Penghambat Degradasi Beta-Karoten. Yogyakarta. Universitas Ahmad Dahlan. Farmasains 2(4) : 177-181

Steel, R.G.D dan J.H. Torrie. 1993. Prinsip dan Prosedur Statistika Suatu Pendekatan 
Biometrik. Penerjemah B. Sumantri. PT. Gramedia Pustaka, Jakarta.

Sutardi. 2016. Kandungan Bahan Aktif Tanaman Pegagan Dan Khasiatnya Untuk Meningkatkan Sistem Imun Tubuh. Balai Pengkajian Teknologi Pertanian Yogyakarta. Jurnal Litbang Pertanian. 35(3):121-130

Utami. 2009. Potensi Daun Alpukat (Persea Americana Mill) Sebagai Sumber Antioksidan Alami. Jurnal Teknik Kimia UPN Jawa Timur. 2 (1) : 58-64.

Wijaya, H., Novitasari, S. Jubaidah. 2018. Perbandingan Metode Ekstraksi Terhadap Rendemen Ekstrak Daun Rambai Laut (Sonneratia Caseolaris L. Engl). Samarinda. Akademi Farmasi Samarinda Jurnal Ilmiah Manuntung, 4(1) : 79-83

Yulianingtyas, A., dan B. Kusmantoro. 2016. Optimasi Volume Pelarut dan Waktu Maserasi Pengambilan Flavonoid Daun Belimbing Wuluh (Averrhoa bilimbi L.). Jurnal Teknik Kimia. 10(2):58-64.

Yulianti. D, B, Susilo. R. Yulianingsih. 2014. Pengaruh Lama Ekstraksi Dan Konsentrasi Pelarut Etanol Terhadap Sifat Fisika-Kimia Ekstrak Daun Stevia (Stevia Rebaudiana Bertoni M.) Dengan Metode Microwave Assisted Extraction (Mae). Jurnal Bioproses Komoditas Tropis. 2(1):35-41 